\title{
PROJECTS OF HIGH-TEMPERATURE NUCLEAR REACTORS
}

(Overview. Part 2)

\author{
J. Ekmanis, E. Tomsons, N. Zeltiņšs \\ Institute of Physical Energetics \\ 21 Aizkraukles Str., Riga, LV-1006, LATVIA
}

\begin{abstract}
Part 2 of the overview gives emphasis to the projects of high-temperature NRs, whose development is an area of active engagement for the specialists from the USA, France, Japan, Russia, China, the Netherlands, and Germany. Projects of several powerful NRs of the HTGR type for commercial use had been worked out in the USA and Germany already by 1970 but not yet implemented.
\end{abstract}

Key words: nuclear fuels, high-temperature nuclear reactors, nuclear power plant.

\section{INTRODUCTION}

The high-temperature NRs are developed with specific design solutions, structure of the active zone, and disposition of the equipment, which ensures good characteristics for the reactor. Melting of the active zone in the NR is eliminated since it contains graphite with the sublimation temperature of $3600{ }^{\circ} \mathrm{C}$. If helium gas for cooling the active zone is lost, the temperature does not rise rapidly, which is ensured by a considerable heat capacity of the active zone and the materials surrounding it, and by the heat escape into the environment. Besides, since the high-temperature NR has a remarkable negative temperature reactivity excluding spontaneous rise in its heat capacity, no additional emergency cooling systems are required. This is ensured also by a low density of the heat capacity in the active zone (3-6 $\mathrm{MW}_{\mathrm{th}} / \mathrm{m}^{3}$ ), as well as increased (2.5 to 3 times) height of the active zone in relation to its diameter. In order to provide the possibility to make individual structural elements of high quality NR modules at the factory, to transport and assemble them on site, the maximum heat capacity of such a NR does not exceed (400-600) $\mathrm{MW}_{\mathrm{th}}$.

\section{CONSTRUCTION OF HIGH-TEMPERATURE NUCLEAR REACTORS}

In November, 2005 a construction plan was confirmed in China for a larger version of the HTR-10 type NRs - the "HTR-PM" (High Temperature Gas-Cooled Reactor - Pebble Bed Module) (Table 6) [15]. A project was offered for the construction with two NR modules where the heat capacity of each module would be $250 \mathrm{MW}_{\text {th }}$, and with one steam turbine which drives a $210 \mathrm{MW}_{\mathrm{e}}$ generator of electrical power $(\eta=42 \%)$. The nuclear fuel to be used in the improved NR of the 
HTR-10 type will be 520000 balls of uranium enriched with $9 \%$ of the ${ }^{235} \mathrm{U}$ isotope. Each spherical element of nuclear fuel contains 12000 nuclear fission TRISO-coated particles. Into particles with the diameter of $\sim 1 \mathrm{~mm}$ the $0.5 \mathrm{~mm}$ nuclei of uranium dioxide $\left(\mathrm{UO}_{2}\right)$ are inserted. The spherical element contains $7 \mathrm{~g}$ of nuclear fuel. It is planned to reach the average combustion depth of nuclear fuel not less than $80 \mathrm{GW} \cdot \mathrm{d} / \mathrm{t}$. The active zone is cooled by helium gas supplied into the NR at $250{ }^{\circ} \mathrm{C}$ and heated to $750{ }^{\circ} \mathrm{C}$. The He pressure is $7 \mathrm{MPa}$. The operating period of a HTR-PM type NR will be 60 years with $85 \%$ load factor. The construction started in April, 2011 in Shidaowan (near Rongcheng, Shandong Province). Its completion is scheduled for 2015. The NPP with a HTR-PM-type NR with 18 NR modules is intended to reach the total electric capacity of $3780 \mathrm{MW}_{\mathrm{e}}$. By developing the NRs of the HTR-PM type during the next stage it is intended to increase the temperature of heat carrier to $950{ }^{\circ} \mathrm{C}$ (later to $1000{ }^{\circ} \mathrm{C}$ ) in order to ensure hydrogen production from water by thermochemical methods.

Table 6

Construction of high-temperature nuclear reactors

\begin{tabular}{|c|c|c|c|c|c|}
\hline \multirow[b]{2}{*}{ Reactor type } & \multicolumn{2}{|c|}{ Capacity } & \multirow[b]{2}{*}{ Nuclear fuel } & \multicolumn{2}{|c|}{ Helium in the active zone } \\
\hline & $\begin{array}{l}\text { heat, } \\
\text { MW }_{\text {th }}\end{array}$ & $\begin{array}{c}\text { electric, } M \\
\mathrm{~W}_{\mathrm{e}}\end{array}$ & & $\begin{array}{c}\text { temperature, }{ }^{\circ} \mathrm{C} \\
\text { output/input }\end{array}$ & $\begin{array}{l}\text { pressure, } \\
\mathrm{MPa}\end{array}$ \\
\hline $\begin{array}{l}\text { HTR-PM (High } \\
\text { Temperature Reactor- } \\
\text { Pebble Bed Module) }\end{array}$ & $2 \times 250$ & 210 & globe-shaped & $750 / 250$ & 7 \\
\hline $\begin{array}{l}\text { GT-MHR (Gas Turbine } \\
\text { Modular Helium Reactor) }\end{array}$ & 600 & 286 & prism-shaped & $850 / 490$ & 7.15 \\
\hline
\end{tabular}

A gas turbine modular helium-cooled nuclear reactor NR GT-MHR is an improved and advanced international HTGR-type NR. The project was developed using the experience of the USA FORT ST. VRAIN NR with $842 \mathrm{MW}_{\text {th }}$ heat capacity (1976-1989). The main executors of the project are: General Atomics, the USA; OKBM Afrikantov in Nizhny Novgorod, Russia, supported by the Japanese company Fuji Electric [16]. In the starting period of designing, the French company Areva was involved in the development of the NR but abandoned the GT-MHR project when initiated the ANTARES project. The documentation of the project was completed in 2001, but the building of the prototype in Russia did not evolve for a long time. The construction of the experimental GT-MHR-type NR started in Russia, in Sversk near Tomsk in 2009. The planned heat capacity of the NR is $600 \mathrm{MW}_{\text {th. }}$. With a gas turbine, the electric capacity of the PGU is planned to be $286 \mathrm{MW}_{\mathrm{e}}(\eta \sim 48 \%)$. The cylindrical active zone contains 102 sixsided graphite blocks with channels for the nuclear fuel elements, control rods and circulation of He gas. The particles of nuclear fuel $0.65-0.85 \mathrm{~mm}$ in diameter are made by the TRISO coating technology and will be inserted in graphite cylinders (diameter $13 \mathrm{~mm}$, height $51 \mathrm{~mm}$ ). As nuclear fuel, uranium dioxide $\left(\mathrm{UO}_{2}\right)$ enriched by $19.9 \%$ with ${ }^{235} \mathrm{U}$ isotope and plutonium (earlier used for nuclear weapon). The spectrum of neutrons in the active zone of the GT-MHR type NR will ensure complete removal of the transuranium elements (neptunium, plutonium, americium and curium) from the used light water fuel of the NR (PWR). The six-sided 
graphite element is $79.3 \mathrm{~cm}$ long, and the distance between the edges is $36 \mathrm{~cm}$. For cooling the active zone, $\mathrm{He}$ gas with $7.1 \mathrm{MPa}$ pressure will be used by heating it from $490{ }^{\circ} \mathrm{C}$ to $850{ }^{\circ} \mathrm{C}$. The mass of $\mathrm{He}$ gas through the active zone will be $320 \mathrm{~kg} / \mathrm{s}$. The average release of thermal energy in the active zone will be $6.5 \mathrm{MW}_{\mathrm{th}} / \mathrm{m}^{3}$, the combustion depth of nuclear fuel $-220 \mathrm{GW} \cdot \mathrm{d} / \mathrm{t}$. Once in every 18 months a half of the nuclear fuel used in the active zone is to be replaced. The service life of the NR will be 60 years, the planned cost of the electric energy $\sim 1.62 \mathrm{cent} / \mathrm{kWh}_{\mathrm{e}}$.

\section{THE OFFERED PROJECTS \\ OF THE HIGH-TEMPERATURE NUCLEAR REACTORS}

In order to develop high-temperature NRs, specialists offer several HTGRtype NRs projects among which more familiar are: PBMR (Pebble Bed Modular Reactor) with globe-shaped (graphite sphere) elements of nuclear fuel, EM2 (Energy Multiplier Module), ANTARES (Areva SC-HTGR - Australian National Tandem Accelerator for Applied Research), МГP-T (MGR-T) - a source of energy for the production of hydrogen, GTHTR300 and GTHTR300C (Gas Turbine High Temperature Reactors) with graphite prism-shaped elements (Table 7). For cooling the HTGR-type NR helium gas will be used.

Table 7

The offered projects of the high-temperature nuclear reactors

\begin{tabular}{|c|c|c|c|c|c|}
\hline \multirow[b]{2}{*}{ Reactor type } & \multicolumn{2}{|c|}{ Capacity } & \multirow[b]{2}{*}{ Nuclear fuel } & \multicolumn{2}{|c|}{ Helium in the active zone } \\
\hline & $\begin{array}{l}\text { heat, } \\
\text { MW }_{\text {th }}\end{array}$ & $\begin{array}{l}\text { electric, } \\
\mathrm{MW}_{\mathrm{e}}\end{array}$ & & $\begin{array}{c}\text { temperature, }{ }^{\circ} \mathrm{C} \\
\text { output/input }\end{array}$ & $\begin{array}{c}\text { pressure, } \\
\mathrm{MPa}\end{array}$ \\
\hline $\begin{array}{l}\text { 1. PBMR (a Pebble Bed } \\
\text { Modular Reactor) }\end{array}$ & 400 & 165 & globe-shaped & $900 / 500$ & 7 \\
\hline $\begin{array}{l}\text { 2. EM2 (an Energy } \\
\text { Multiplier Module) }\end{array}$ & 500 & 240 & prism-shaped & $850 /$ & \\
\hline $\begin{array}{l}\text { 3. МГР-Т (MGR-T - } \\
\text { a source of energy } \\
\text { for the production } \\
\text { of hydrogen) }\end{array}$ & 600 & 185 & prism-shaped & $800-850 /$ & 7.5 \\
\hline $\begin{array}{l}\text { 4. ANTARES [Areva } \\
\text { SC-HTGR] } \\
\text { (an Australian National } \\
\text { Tandem Accelerator for } \\
\text { Applied Research) }\end{array}$ & 625 & 250 & prism-shaped & $850 / 400$ & \\
\hline $\begin{array}{l}\text { 5. 1. GTHTR300 } \\
\text { (a Gas Turbine High } \\
\text { Temperature Reactor) }\end{array}$ & 600 & 274 & prism-shaped & $850 / 587$ & 6.9 \\
\hline $\begin{array}{l}\text { 5. 2. GTHTR300C } \\
\text { (a Gas Turbine High } \\
\text { Temperature Reactor) }\end{array}$ & 600 & 202 & prism-shaped & $950 / 594$ & 5.1 \\
\hline
\end{tabular}

The prototype of the PBMR-type NR: planned site South Africa, Koeberg (near Capetown). The project has been worked out by international companies applying the experience gained in Germany under the leadership of the South African Electricity Supply Commission (ESKOM). The factory producing nuclear 
fuel will be situated in Pelindada, close to Pretoria. The NR will utilise the globeshape graphite elements of nuclear fuel developed by German specialists. The heat capacity of a full-scale NR module is intended to be $400 \mathrm{MW}_{\text {th }}$, and the electric capacity of the PGU $-165 \mathrm{MW}_{\mathrm{e}}$. The active zone will have approximately 450000 balls of nuclear fuel $[17,18]$. A ball $(6 \mathrm{~cm}$ in diameter) contains about 15000 particles of nuclear fuel $\left(\mathrm{UO}_{2}\right)$, the diameter of each particle being $\sim 0.92 \mathrm{~mm}$. The ball contains $9 \mathrm{~g}$ of uranium with $9.6 \%$ enrichment by ${ }^{235} \mathrm{U}$ isotope. The efficiency of the PGU will be $41 \%$. The active zone $(3.5 \mathrm{~m}$ in diameter and $10 \mathrm{~m}$ in height) will be cooled by helium gas under the pressure of $7 \mathrm{MPa}$. The temperature of helium gas entering the NR active zone and leaving it will be $500{ }^{\circ} \mathrm{C}$ and $900{ }^{\circ} \mathrm{C}$. To produce electric energy, a gas turbine will be used.

Starting from 2004, the South African government has been attaching great importance to development of electric capacities via HT NRs with globe-shaped nuclear fuel. Therefore, from 20 to 30 PBMR-type NRs with $165 \mathrm{MW}_{\mathrm{e}}$ modules are to be built. At the present time $94 \%$ of electric energy in the country is ensured by power plants running on coal.

The recent development plan offers the project of a NR with a lower heat capacity of the module $\left(200 \mathrm{MW}_{\mathrm{th}}\right)$. A steam turbine is intended to be used for the production of electric energy with an $80 \mathrm{MW}_{\mathrm{e}}$ electric capacity. According to the project, the active zone is cooled by $\mathrm{He}$ gas heated to $720{ }^{\circ} \mathrm{C}$. In the steam generator this gas escaping the active zone produces steam from water. The globeshaped elements of nuclear fuel (South African production) have been successfully tested in Russia. In the USA the use of such type PBMR-type NRs is also targeted. In 2010 the South African government announced that due to the lack of financial resources (to be expired by the end of 2011) the project is suspended. Further development of the project is for the time being unclear.

The Energy Multiplier Module EM2 is a modified version of the GT-MHR project offered in February, 2010 by the US leading Nuclear Energy Research Institute. The EM2 is a high-temperature helium-cooled fast-neutron $500 \mathrm{MW}_{\text {th }} \mathrm{NR}$. Helium gas in the active zone is heated to $850{ }^{\circ} \mathrm{C}$. The electric capacity of the PGU is $240 \mathrm{MW}_{\mathrm{e}}$. To operate the EM2-type NR, it will be possible to add $20 \mathrm{t}$ of nuclear fuel used up by the water-cooled PWR-type NR, or depleted uranium after the separation of ${ }^{235} \mathrm{U}$ isotope at the uranium enrichment, together with $22 \mathrm{t}$ of the uranium ( 12\% of the ${ }^{235} \mathrm{U}$ isotope) required for running the NR. By radiating the nuclear fuel used up by the PWR-type NR about $4 \mathrm{t}$ of the fission products are removed. The obtained residue is recycled into new nuclear fuel, adding $4 \mathrm{t}$ of the used up nuclear fuel. Changing the nuclear fuel 12 times within 30 years makes it possible to reduce the radioactivity of highly radioactive waste $\sim 25$ times, i.e. to $4 \%$ of the amount which arose in the nuclear fuel used up by the PWR-type NR. By means of a gas turbine the heat of the NR will be used to produce electric energy $(\eta \sim 48 \%)$. Besides, the heat of the EM2-type NR can be employed to ensure diversified processes that require high-temperature heat.

МГP-T (MGR-T): a source of energy for the production of hydrogen. The project was worked out in Russia with several organisations participating. The heat capacity of the NR is intended to be $600 \mathrm{MW}_{\text {th. }}$. It is designed for hydrogen production with the output of 140 ths $\mathrm{m}^{3} / \mathrm{h}$ and intended to consume $211 \mathrm{MW}_{\text {th }}$ to produce hydrogen. Heat capacity of $384 \mathrm{MW}_{\text {th }}$ will be directed to generate 
electricity and to heat helium gas in the active zone under pressure of 7.5 MPa to $800-850{ }^{\circ} \mathrm{C}$. The NR is designed for 60 years' operation. The Russian specialists have estimated that $50 \mathrm{NR}$ blocks of the type are needed to satisfy the present requirement for hydrogen in the country. It is planned to build a demonstration block of this type NR by 2017 and to implement the project together with the hydrogen production unit in 2020.

ANTARES (Areva SC-HTGR) - a high-temperature NR in which technical solutions of the GT-MHR-type NR are embodied. Besides the French company Areva, specialists from the Japanese Fuji Electric are involved in development of the project [19]. The NR is to work on prism-shaped blocks of nuclear fuel (heat capacity $625 \mathrm{MW}_{\mathrm{th}}$, PGU electric capacity $250 \mathrm{MW}_{\mathrm{e}}$ ). The temperature of heat carrier at the exit from the active zone will be $750{ }^{\circ} \mathrm{C}$, ensuring operation of a steam turbine. A helium-nitrogen mixture in the NR secondary cooling system excludes a possibility to pollute the hydrogen production equipment with radionuclides from the active zone. According to the project, the working temperature in the active zone and cooling system is $850{ }^{\circ} \mathrm{C}$, while in future it will be raised up to $1000{ }^{\circ} \mathrm{C}$.

JAERI (GTHTR300) high-temperature NR (Fig. 5) with a gas turbine $\left(600 \mathrm{MW}_{\text {th }}\right.$ in one module) has been worked out based on the results of running the HTTR-type NRs of the Japanese Atomic Energy Research Institute [20, 21]. It uses improved nuclear fuel elements with a $14 \%$ uranium enrichment of ${ }^{235} \mathrm{U}$ isotope, reaching a higher combustion degree $(120 \mathrm{GW} \cdot \mathrm{d} / \mathrm{t})$. For cooling the active zone $\mathrm{He}$ gas under pressure of $6.9 \mathrm{MPa}$ is used, heating it from $587{ }^{\circ} \mathrm{C}$ to $850{ }^{\circ} \mathrm{C}$. With the gas turbine intended for electricity production the efficiency of heat use will be $47 \%\left(274 \mathrm{MW}_{\mathrm{e}}\right)$. At $\mathrm{He}$ gas heated from $663{ }^{\circ} \mathrm{C}$ to $950{ }^{\circ} \mathrm{C}$, the efficiency of the heat use will be $50 \%$ and the capacity of the produced electric energy $-300 \mathrm{MW}_{\mathrm{e}}$.

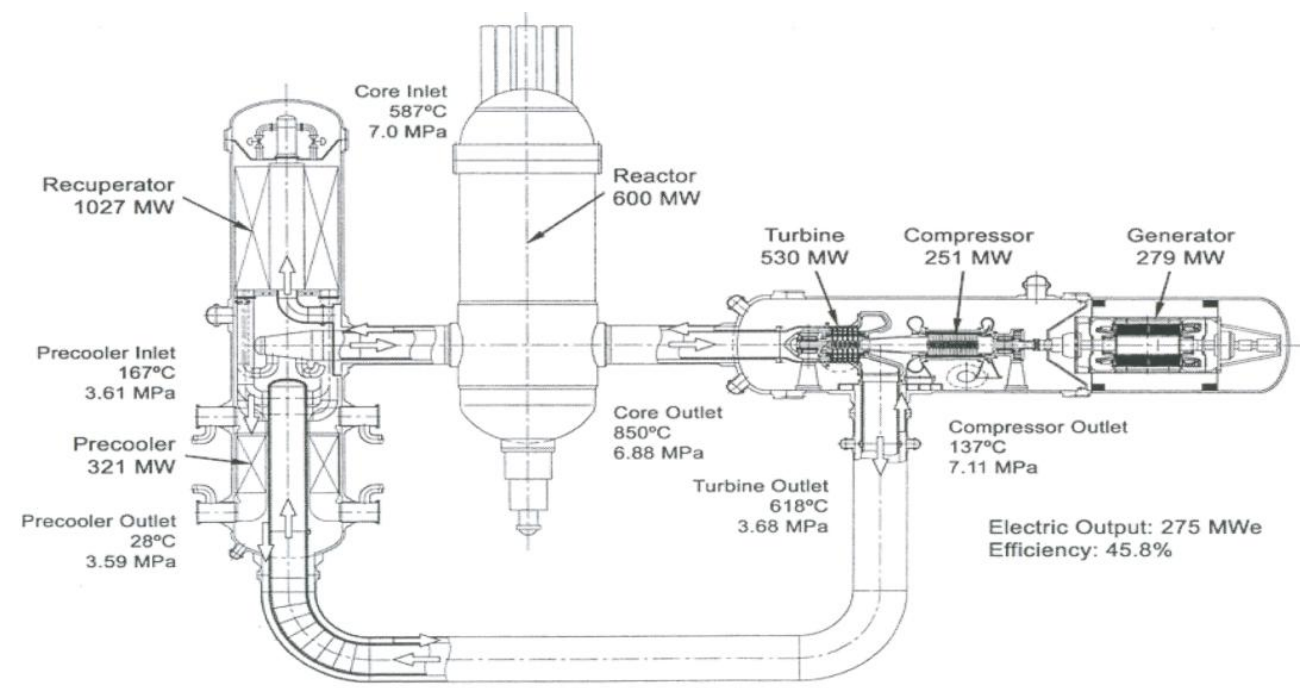

Fig. 5. A view of the GTHTR300-type nuclear reactor with a unit for production of electric energy.

Ninety six-sided $8 \mathrm{~m}$ long columns of nuclear fuel are arranged in a ring enclosing the graphite neutron reflector. The graphite block of nuclear fuel has 
$0.55 \mathrm{~mm}$ nuclear fission particles covered with a protective $0.14 \mathrm{~mm}$ layer. Every two years the NR is refuelled (the fuel remains in active zone for four years). The GTHTR300C (Fig. 6) as a NR version $\left(600 \mathrm{MW}_{\mathrm{th}}, 202 \mathrm{MW}_{\mathrm{e}}\right.$ ) has been worked out for operation in the cogeneration mode for electricity and hydrogen production. Helium gas under pressure of 5.1 MPa in the active zone is to be heated from $594{ }^{\circ} \mathrm{C}$ to $950{ }^{\circ} \mathrm{C}$. It will be possible to produce hydrogen from water in a thermochemical process, with efficiency of $45-55 \%$

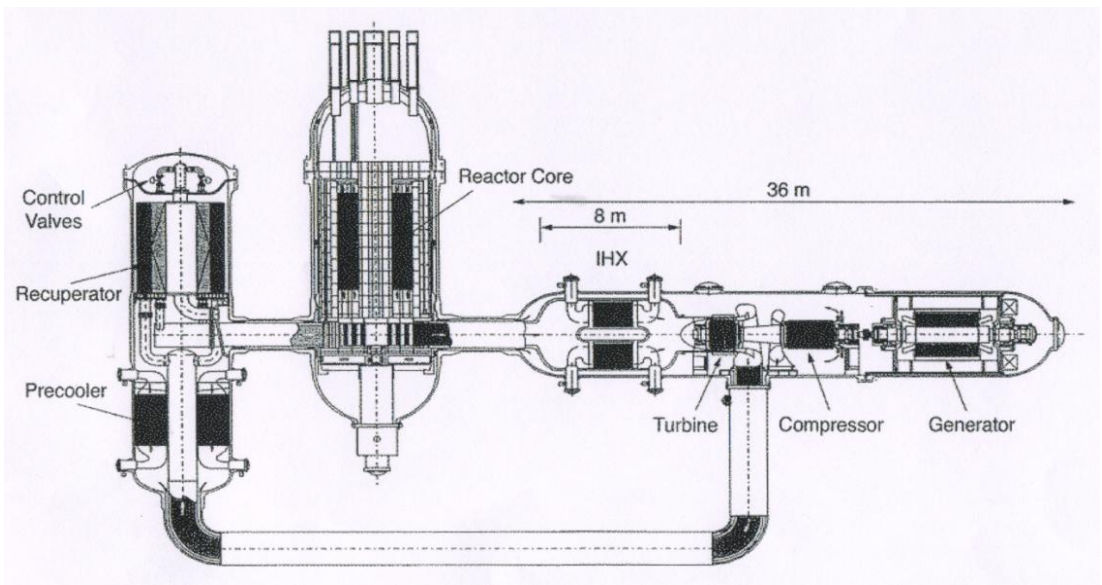

Fig. 6. A view of the GTHTR300C-type NR

with the units for production of electric energy and hydrogen.

\section{THE IV GENERATION NRs FOR PRODUCTION OF HYDROGEN}

In the mid-2001, at the Generation IV International Forum (GIF) the necessary measures for development of the next generation NRs were discussed [22]. The GIF was represented by such countries as the USA, Argentina, Brazil, Canada, China, France, Japan, South Korea, South Africa, Switzerland, Great Britain, etc., in which nuclear energy is essential - now and in the future. Most of the countries have resolved to work out together nuclear technologies of the next generation. Russia joined the mentioned countries in August, 2009. After two years the GIF announced that technologies of six reactors were selected which would be most appropriate for further development. The selection was determined by their highly pure (not polluting the environment), safe and economically profitable operation, which suits increased consumption of energy and its sustainable use. One of the technologies offered has water cooling, two - helium cooling; the rest are cooled using lead-bismuth, sodium, and fluorine salts. The last three technologies are meant for a low pressure. The temperature of the active zone cooler in the offered technologies is from $510{ }^{\circ} \mathrm{C}$ to $1000{ }^{\circ} \mathrm{C}$ (in the water-cooled NRs it is $\sim 330{ }^{\circ} \mathrm{C}$ ). Four of them are at a high development stage; wide operational experience is acquired (data on IV generation NRs for hydrogen production see in Table 8).

These nuclear technologies will be safeguarded against any possibility to apply the material of the used nuclear fuel to the military needs and against the attacks by terrorists. The projects are subject to further development and perfection on an international scale. The present costs, according to the initial estimations for 15 years, are 6 billion dollars. About $80 \%$ of the costs are financed by the USA, 


\begin{tabular}{|c|c|c|c|c|c|}
\hline 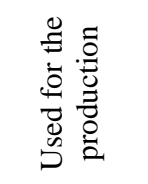 & 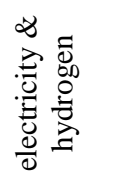 & 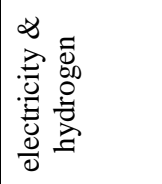 & 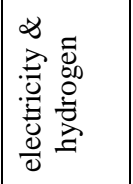 & 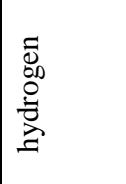 & 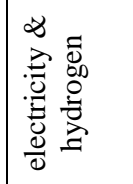 \\
\hline 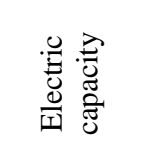 & 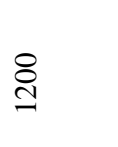 & 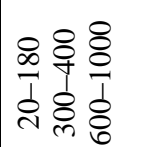 & 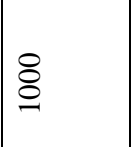 & $\begin{array}{l}8 \\
0 \\
1 \\
8 \\
8\end{array}$ & 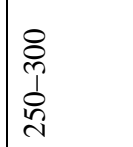 \\
\hline 可 $\frac{0}{0}$ & 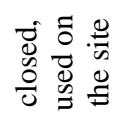 & 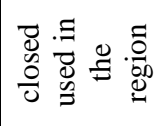 & $\begin{array}{l}\vec{J} \\
0 \\
0 \\
0\end{array}$ & 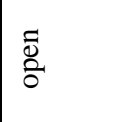 & 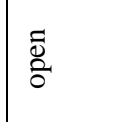 \\
\hline $\begin{array}{l}\bar{\Xi} \\
\stackrel{\overrightarrow{\mid}}{1}\end{array}$ & 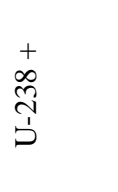 & $\begin{array}{l}+ \\
\infty \\
\stackrel{\sim}{1} \\
D\end{array}$ & 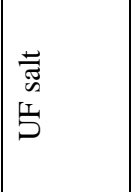 & 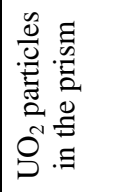 & 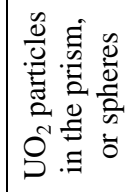 \\
\hline 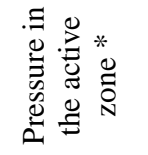 &. & 孞 & 孞 & & $\stackrel{.50}{: 00}$ \\
\hline 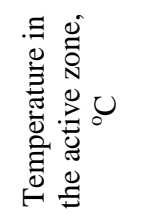 & $\stackrel{\infty}{\infty}$ & $\begin{array}{l}8 \\
\infty \\
\infty \\
0 \\
\infty \\
+ \\
+\end{array}$ & $\begin{array}{l}8 \\
\infty \\
0 \\
8 \\
8\end{array}$ & $\frac{8}{8}$ & $\begin{array}{l}8 \\
\frac{8}{1} \\
8 \\
8\end{array}$ \\
\hline 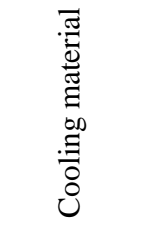 & 害 & 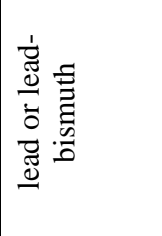 & 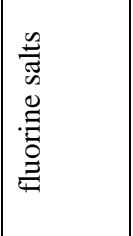 & 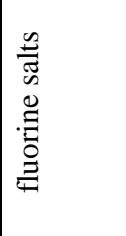 & 竭 \\
\hline 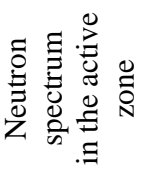 & $\underset{\mathbb{s}}{\vec{s}}$ & $\vec{g}$ & 恚 & 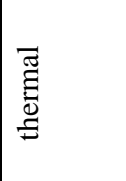 & 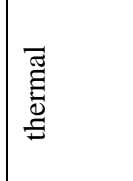 \\
\hline 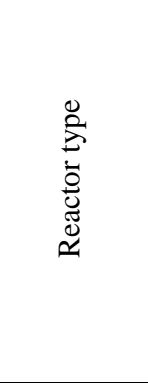 & 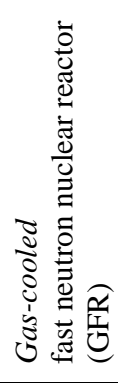 & 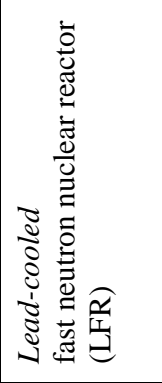 & 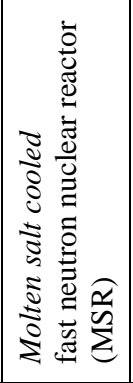 & 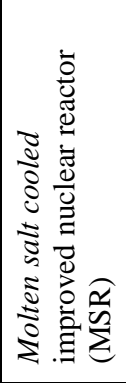 & 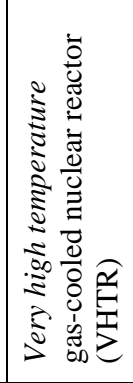 \\
\hline
\end{tabular}


Japan and France. Most of these six systems will apply the closed fuel cycle and reuse of the nuclear fuel in order to increase the basic resources of the nuclear fission materials and reduce the amount of the high-level waste to be buried. Four of the planned technologies under discussion are designed not only for the production of electric energy but also of hydrogen from water by thermochemical methods (Table 8).

A gas-cooled fast neutron nuclear reactor (GFR). This type of NR is similar to the others already operating (or still being developed) with He cooling. The NR of GFR-type is that of high-temperature $\left(\sim 850{ }^{\circ} \mathrm{C}\right)$. The applied technologies will be suitable for the production of electric energy, hydrogen from water, or in other high-temperature industrial processes. The PGU of the GFR-type NR can reach $1200 \mathrm{MW}_{\mathrm{e}}$ of electric capacity. The active zone of the NR is placed in a pressure-resistant steel container provided with several heat-removal loops.

Electricity is to be produced by a heated helium gas turbine. In the active zone of a GFR-type NR with the fast neutron spectrum it will be possible to produce nuclear fuel using depleted uranium, i.e. the uranium ${ }^{238} \mathrm{U}$ isotope, after the enrichment process with separation of an uranium ${ }^{235} \mathrm{U}$ isotope proportion. It will be possible to include into the used fuel also other fissile and reproducing materials as well as plutonium from $15 \%$ to $20 \%$. NRs of the type will reprocess the used nuclear fuel on site, with putting the obtained actinides (from the used nuclear fuel) into the active zone for repeated radiation with neutrons in order to reduce the amount of the long-lived radioactive waste.

Although the USA scientists have been working at the projects of hightemperature NRs since 1970 (i.e. after the operation of the "PEACH BOTTOM-1" and "FORT ST. VRAIN") no NR has yet been built. The obtained information will be applied in the projects of the IV generation nuclear reactors the prototypes of which are expected only after the year 2025 .

The construction of an experimental pilot project (EURATOM-supported) with a heat capacity of $80 \mathrm{MW}_{\text {th }}$ is planned for 2014. EURATOM, France, Japan and Switzerland have signed the agreement on elaboration of the GFR-type NR technologies.

A lead-cooled fast neutron nuclear reactor (LFR) is an easy-controlled fast neutron NR in which it will be possible to use depleted uranium (i.e. with a lower concentration of ${ }^{235} \mathrm{U}$ isotope as compared with natural uranium) or a matrix of thorium fuel; also, actinides from the nuclear fuel used up by the LWR-type NR could be burnt. For cooling the active zone the liquid lead or lead-bismuth metals will be used (under a low pressure during the operation). In case of accident the cooler will ensure natural convection of heat carrier that removes the decay heat of the fission products. The nuclear fuel is in the form of a metal or a nitride. It is intended to make a low-capacity $\left(20-180 \mathrm{MW}_{\mathrm{e}}\right) \mathrm{NR}$ PGU with a nuclear fuel replacement cycle of 15-20 years for small networks or for the needs of developing countries.

Apart from that, NR modules are envisaged with the electric capacity of PGU (300-400) $\mathrm{MW}_{\mathrm{e}}$ and even greater - up to $1400 \mathrm{MW}_{\mathrm{e}}$. Operation of the NR at the temperature of $550{ }^{\circ} \mathrm{C}$ can be easily carried out; using resistant materials, it will be possible to reach a temperature of $800{ }^{\circ} \mathrm{C}$ for the production of hydrogen from 
water. A two-stage development programme is planned: first, it is envisaged to master the NR for the work at a comparatively low temperature, with implementation by 2025; higher temperature projects are to be completed by 2035 .

The LFR-type NRs correspond to the technology of the Russian "BREST" fast neutron reactor based on the 80 years' operating experience using a lead or lead-bismuth cooler (mainly the submarine NRs with $\mathrm{U}+\mathrm{Pu}$ nitride as nuclear fuel). Besides, the GIF takes into account the experience gained from the experimental projects "STAR" (the USA) and "LSPR" (Japan) as these installations have lead and lead-bismuth cooling.

Initially, the LFR development was centred on two basin-type NR projects: a $20 \mathrm{MW}_{\mathrm{e}}$ U.S. mobile NR (SSTAR - Small Secure Transportable Autonomous Reactor), and a $600 \mathrm{MW}_{\mathrm{e}}$ European lead-cooled system (ELSY - European LeadCooled System).

A molten salt-cooled reactor (MSR). In about the year 1960 the USA worked out a low capacity $\left(8 \mathrm{MW}_{\text {th }}\right.$ ) molten salt fast neutron NR prototype (MSRE - Molten Salt Reactor Experimental), which was running at the Oak Ridge laboratory approx. four years. The uranium ${ }^{235} \mathrm{U}$ isotope is melted in sodium and zirconium fluoride and at $860{ }^{\circ} \mathrm{C}$ it circulates through the graphite neutron decelerator (moderator). Now there is a renewed interest in molten salt in Japan, Russia, France and the USA. Not long ago, studies were made for the fuel components of thorium and uranium ${ }^{233} \mathrm{U}$ melted in the lithium and beryllium fluoride cooler. Particularly the MSR-type NR fuel cycle will ensure considerable reduction in the highly radioactive waste of fission products.

Currently, two MSR-type NR versions are under elaboration. The uranium fuel of the MSR-type NR is solved in the cooler of fluorine salts which circulate through the channels in the graphite blocks of active zone. The PGU electric capacity in the project is to be $1000 \mathrm{MW}_{\mathrm{e}}$.

The nuclear fission products are removed from the active zone uninterruptedly, and the actinides can be considerably reduced. Plutonium and other actinides can be added to the uranium ${ }^{238} \mathrm{U}$ isotope making up the nuclear fuel for the MSR-type NR. The cooling liquid at the $700{ }^{\circ} \mathrm{C}$ temperature is under low pressure.

In the future it is planned to operate molten salt at a temperature of $800{ }^{\circ} \mathrm{C}$. The secondary cooling system, when connected with a turbine, will be used for the electric energy production as well as for the production of hydrogen from water applying thermochemical methods. In contrast to the solid nuclear fuel NRs, a MSR-type system has less nuclear fission materials. The MSR-type NR is economically most competitive among the energetic NRs; it burns efficiently actinides and expands well the resources of nuclear fuel.

A very high temperature gas-cooled nuclear reactor (VHTR). These are based on remarkable experience and present NRs with a graphite neutron decelerator and helium gas cooling. EURATOM, Canada and Japan have signed an agreement on the elaboration of the equipment of this type. The active zone will be formed of prismatic blocks as in the Japanese HTTR-type NR, or globe-like elements of nuclear fuel as in the Chinese HTR-10-type NR; or as in HTR-PM- and PBMR-type NRs that are under development in South Africa. The temperature of the gas escaping from the active zone will be $900{ }^{\circ} \mathrm{C}$ with a purpose to reach 
$1000^{\circ} \mathrm{C}$, which would ensure implementation of the thermochemical hydrogen production technology. By means of an intermediary heat exchanger it is possible to produce electric energy in the cogeneration mode, with the help of a highly efficient gas turbine. After the nuclear fuel is used up, its reprocessing (recycling) is not envisaged. It is intended to develop a $600 \mathrm{MW}_{\text {th }}$ module. The VHTR-type NR can reach a high degree of the nuclear fuel combustion - (150-200 $\mathrm{GW} \cdot \mathrm{d} / \mathrm{t})$, full passive safety, low operation and maintenance costs. By now, EURATOM, Canada, France, Japan, China, Korea, Switzerland and the USA have signed an agreement on cooperation in the development of a VHTR-type NR.

In 2010 the European Commission started the European Sustainable Nuclear Industrial Initiative (ESNII) corresponding to the projects of the IV generation fast neutron reactors as part of the EU plan in order to promote energy technologies with low carbon contents. The Commission will continue its support to the other initiatives, such as the use of biomass, wind, sun, or, e.g. the development of relevant electric networks and storage of carbon. The aim of the ESNII is to show that the IV generation NR technologies can solve the problem of rational utilisation of nuclear fuel ensuring long-term waste management and expand the use of NRs for not only electric energy but also hydrogen production as well as industrial application of heat and desalination of the sea water.

\section{CONCLUSIONS}

1. In the development of IV Generation high-temperature nuclear reactors the specialists from the USA, France, Japan, Russia, China, the Netherlands and Germany are actively involved.

2. The high-temperature nuclear reactors are designed with a specific structure of the active zone and arrangement of the technological equipment, which ensures good performance of the reactor (the $41-55 \%$ use of thermal energy; deeper combustion of nuclear fuel as compared with the water-cooled NRs, etc.) as well as higher radiation and nuclear safety. The developed designs provide a remarkable negative temperature reactivity of the reactor, which ensures spontaneous increase in its heat capacity and excludes melting of the active zone.

3. The following of the planned NRs are intended to produce both hydrogen and electric energy:

- a Gas-Cooled Fast Neutron Nuclear Reactor (GFR);

- a Lead-Cooled Fast Neutron Nuclear Reactor (LFR );

- a Molten Salt Cooled Nuclear Reactor (MSR );

- a Very High-Temperature Gas-Cooled Nuclear Reactor (VHTR ).

4. As perspective high-temperature nuclear reactors for the needs of Latvia after the year 2030 would be NRs of the PBMR-type with globe-shaped elements or of the GTHTR300C-type with prism-shaped elements of the nuclear fuel. Reactors of the type will be intended for the production of electric energy \& hydrogen.

\section{ACKNOWLEDGEMENT}

This work has been supported by the National Research Programme 20102013 "Technologies for Innovative Production and Use of Energy Resources and 
Provision of Low Carbon Emissions by Means of Renewable Energy Sources, Support Measure for the Mitigation of Environment and Climate Degradation LATENERGI"

\title{
REFERENCES
}

15. Zuoyi Zhang, Zongxin Wu, Yuanhui Xu, Yuliang Sun, \& Fu Li (2004). Design of Chinese modular high-temperature gas-cooled Reactor HTR-PM. $2^{\text {nd }}$ International Topical Meeting on HIGH TEMPERATURE REACTOR TECHNOLOGY, 8 (China).

16. Kiryushin, A., \& Kodochigov, N. (2002). GT-MHR Project. OKB Mechanical Engineering, 5. Nizhny Novgorod (RF).

17. Ferreira, T. (2003). South Africa's nuclear programme. Science in Africa (Africa's First On-Line Science Magazine), 5.

18. Gittus, J.H. (1999). The ESKOM pebble bed modular reactor. Nuclear Energy, 38 (4), 215-221.

19. Gauthier, J., Brinkmann, G., Copsey, B., \& Lecomte, M. (2004). ANTARES: The HTR/VHTR Project at Framatome ANP. 2nd International Topical Meeting on HIGH TEMPERATURE REACTOR TECHNOLOGY, 13 (China).

20. Kunitomi, K., Yan, X., Shiozawa, S., \& Fujimoto, N. (2004). GTHTR300C for Hydrogen cogeneration. Department of Advanced Nuclear Heat Technology, Oarai Research Establishment JAERI, 11.

21. Kunitomi, K., Yan, X., Shiozawa, S., \& Fujimoto, N. (2004). GTHTR300C for Hydrogen cogeneration. 2nd International Topical Meeting on HIGH TEMPERATURE REACTOR TECHNOLOGY, 11 (China).

22. Generation IV Nuclear Reactors. (2010). World Nuclear Association.

\author{
AUGSTAS TEMPERATŪRAS KODOLREAKTORU PROJEKTI \\ (Pārskata raksts) \\ 2. dalıa
}

J. Ekmanis, E. Tomsons, N. Zeltiņš

Kops avilkums

Augstas temperatūras ar gāzes dzesēšanu HTGR (High Temperature Gas cooled Reactor) tipa kodolreaktoru (KR) izstrādes koncepcija bija piedāvāta 1956. gadā Lielbritānijā. Apmēram tanī pašā laikā minētā tipa KR izstrādi uzsāka Vācijā un ASV. HTGR tipa KR kodoldegviela un kodoldegvielas atražošanas materiāla sīkās daḷiņas ar diametru apmēram $0.5 \mathrm{~mm}$ pārklātas ar vairākām aizsargkārtām un atrodas grafìta neitronu palēninātājā, kas aizsargā dalinas no neitronu palēninātāja un dzesētāja iedarbes. Augstas temperatūras KR bez hēlija gāzes siltumnesēja var izmantot šķidrus metālus (nātriju, svinu vai svina-bismuta sakausējumu) un izkausētu sāli. Pašlaik darbojās divi augstas temperatūras ar hēlija gāzi dzesēti eksperimentālie HTGR tipa KR. Viens Japānā „HTTR” no 1998. gada oktobra (sākts būvēt 1991. gada 15. martā) ar 30 MW $_{\text {th }}$ siltuma jaudu. Otrs Ķ̄inā „HTR-10" no 2000.gada decembra (sākts būvēt 1995. gada14. jūnijā) ar $10 \mathrm{MW}_{\text {th }}$ siltuma jaudu. Ķīnā Shandong provincē 2011.gada aprīlī uzsāka augstas temperatūras „HTR-PM” (High Temperature Gas-cooled Reactor - Pebble bed Module) tipa kodolreaktora celtniecību ar $250 \mathrm{MW}_{\text {th }}$ siltuma jaudu. Augstas temperatūras kodolreaktoru izstrādē pašlaik aktīvi iesaistīti ASV, Francijas, Japānas, Krievijas, Ķīnas, Nīderlandes un Vācijas speciālisti.

07.01.2013. 